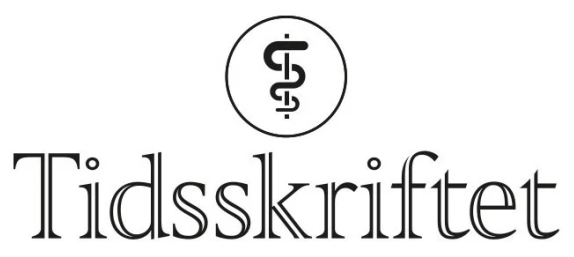

DEN NORSKE LEGEFORENING

\title{
Norge må støtte atomvåpenforbudet
}

\author{
DEBATT
}

\section{SIGNE FLOTTORP}

signe.flottorp@fhi.no

Signe Flottorp er leder i styret for Norske leger mot atomvåpen, forskningssjef ved område for helsetjenester ved Folkehelseinstituttet og forsker ved Avdeling for allmennmedisin, Universitetet i Oslo.

Forfatteren har fylt ut ICMJE-skjemaet og oppgir ingen interessekonflikter.

\section{KNUT MORK SKAGEN}

Knut Mork Skagen er nestleder i Norske leger mot atomvåpen og lege i spesialisering i barne- og ungdomspsykiatri ved St. Olavs hospital.

Forfatteren har fylt ut ICMJE-skjemaet og oppgir ingen interessekonflikter.

\section{BJ ØRN HILT}

Bjørn Hilt er styremedlem i Norske leger mot atomvåpen, styreleder for Internasjonale leger mot atomkrig, overlege i arbeidsmedisin ved St. Olavs hospital og professor emeritus ved Institutt for samfunnsmedisin og sykepleie ved NTNU.

Forfatteren har fylt ut ICMJE-skjemaet og oppgir ingen interessekonflikter.

\section{2. januar 2021 trer FNs atomvåpenforbud i kraft. Det er et historisk gjennombrudd i arbeidet for å avskaffe verdens verste masseødeleggelsesvåpen. Men Norge motarbeider fremgangen.}

FNs avtale om forbud mot atomvåpen ble vedtatt i 2017 av et overveldende flertall av medlemslandene (1). Det var den daværende norske regjeringen som i 2012 startet arbeidet med det humanitære initiativet. Avtalen kom i stand etter press fra bl.a. Den internasjonale kampanjen for å avskaffe atomvåpen (ICAN), som ble startet i 2007 av australske leger, og Internasjonale leger mot atomkrig (IPPNW) (므).

Alle aktiviteter knyttet til atomvåpen er ifølge avtalen forbudt for stater som har sluttet seg til den. Så langt er avtalen signert av 86 stater og ratifisert av 51. Norge er dessverre ikke blant disse. Ved å ikke slutte oss til forbudet stiller vi oss utenfor internasjonal lov og på atomvåpenstatenes side, og vi motarbeider et av de viktigste virkemidlene vi har for nedrustning av atomvåpen. 
Det er ingen juridiske hindre for norsk tilslutning. Vi kan fremdeles være en del av NATOs felles forsvar, men vi må si fra oss muligheten for at våre allierte kan bruke, eller true med å bruke, atomvåpen på våre vegne. Når de humanitære og medisinske konsekvensene av atomvåpenbruk er så godt dokumentert, burde dette være et enkelt valg.

\section{Legers ansvar}

Som en del av vår legegjerning må vi ha et aktivt forhold til farer som truer menneskers helse. Derfor har leger internasjonalt engasjert seg i kampen mot atomvåpen helt siden Marcel Junod fra Det internasjonale Røde Kors som den første utenlandske legen beskrev Hiroshima etter angrepet i 1945.

Enhver bruk av atomvåpen vil ha katastrofale og uopprettelige konsekvenser for mennesker og miljø. Ett enkeltstående angrep vil sette lokal helseinfrastruktur ut av spill og gjøre det umulig å nå frem med hjelp. Eksplosjonen påfører skade og død gjennom lysog varmestråling, ioniserende stråling, trykkbølger og ildstormer. Selv en såkalt begrenset regional konflikt mellom atomvåpenmakter vil føre til en global nedkjøling og risiko for sultkatastrofe for to milliarder mennesker (3-5).

«Selv en såkalt begrenset regional konflikt mellom atomvåpenmakter vil føre til en global nedkjøling og risiko for sultkatastrofe for to milliarder mennesker»

Verdens legeforening støtter FNs atomvåpenforbud og oppfordrer nasjonale legeforeninger til å engasjere seg for å få sitt lands regjering til å slutte seg til forbudet (므). Det samme gjør Den internasjonale Røde Kors-komiteen (ICRC), Den internasjonale føderasjonen av medisinstudentforeninger (IFMSA) og Verdens føderasjon av folkehelseforeninger (WFPHA).

\section{Ingen unnskyldninger}

Enkelte hevder at FNs atomvåpenforbud krever at landene som slutter seg til avtalen, ensidig skal kvitte seg med sine atomvåpen. Det er feil. Det skal forhandles om gjensidig og verifiserbar avskaffelse av atomvåpen (1ํ).

Det argumenteres også med at NATOs atomparaply er avgjørende for Norges sikkerhet. Men i en fersk rapport, utført av Folkerettsinstituttet på vegne av Norske leger mot atomvåpen, påpeker flere kilder at atomparaplyen ikke bidrar til sikkerhet for Norge og at avskrekkingstrusselen mangler eller har mistet troverdighet (7.).

Bruk eller trussel om bruk av atomvåpen er uetisk, inhumant - og nå også ulovlig.

Noen mener at leger og andre helsearbeidere trer ut av sin profesjonelle rolle og driver med politikk når de engasjerer seg i kampen mot atomvåpen. Det er heller ikke riktig. Tvert imot innebærer legerollen at vi må støtte atomvåpenforbudet og kjempe for en verden uten atomvåpen, slik Verdens legeforening har erklært (5). Vi må forebygge det vi ikke kan kurere. For å fullføre det livsviktige arbeidet med å forebygge atomkrig må leger og andre helsearbeidere fortsette å engasjere seg, både nasjonalt og internasjonalt. 


\section{LITTERATUR}

1. Treaty on the Prohibition of Nuclear Weapons. New York: United Nations, 2017. http://undocs.org/A/CONF.229/2017/8 Lest 18.1.2021.

2. Mæland JG, Akhtar SN, Hilt B et al. Atomvåpenforbud, nobelpris og legers innsats. Tidsskr Nor Legeforen 2018; 138. doi: 10.4045/tidsskr.18.0452. [PubMed][CrossRef]

3. Norske leger mot atomvåpen. Hvorfor atomvåpen må avskaffes. https://legermotatomvapen.no/news/183/details/hvorfor-atomvapen-ma-avskaffes-ny-publikasjon Lest 18.1.2021.

4. Hilt B. Global hungersnød etter regional atomkrig. Tidsskr Nor Legeforen 2012; 132:1434. [PubMed] [CrossRef]

5. Helfand I. Nuclear famine: Two billion people at risk? Global impacts of limited nuclear war on agriculture, food supplies, and human nutrition. Boston/Washington DC: International Physicians for the Prevention of Nuclear War/Physicians for Social Responsibility, 2013. https://www.ippnw.org/pdf/nuclear-famine-two-billion-at-risk-2013.pdf Lest 18.1.2021.

6. World medical association statement on nuclear weapons. https://www.wma.net/policiespost/wma-statement-on-nuclear-weapons/ Lest 18.1.2021.

7. Hellestveit C, Egeland K. Nato, Norge og kjernevåpen. Folkerettsinstituttet, 2020. https://legermotatomvapen.no/media/files/2020norgenatoogatomvapenegelandhellestveitfolkerettsi nstituttet_1.pdf Lest 18.1.2021.

Publisert: 21. januar 2021. Tidsskr Nor Legeforen. DOI:10.4045/tidsskr.21.0043

Mottatt 18.1.2021, godkjent 18.1.2021.

(C) Tidsskrift for Den norske legeforening 2023. Lastet ned fra tidsskriftet.no 26. april 2023. 